\title{
Influence of Phosphorus on Growth and Yield of Promising Varieties of Lentil (Lens culinaris L. Medik)
}

\author{
Tophia Yumnam*, Edwin Luikham and A. Herojit Singh
}

Department of Agronomy, Department of Soil Science and Agricultural Chemistry, College of Agriculture, Central Agricultural University, Imphal-795004, Manipur, India

*Corresponding author

\section{A B S T R A C T}

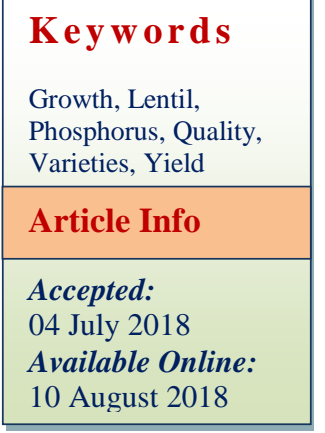

A field experiment was undertaken during the rabi season of 2016-17 at Research Farm of Agronomy, College of Agriculture, CAU, Imphal to study the effect of phosphorus (0, 20, 40 and $60 \mathrm{~kg} \mathrm{P}_{2} \mathrm{O}_{5} / \mathrm{ha}$ ) on growth and yield of three lentil varieties (PL4, HUL 57 and DPL 62).Application of $40 \mathrm{~kg} \mathrm{P}_{2} \mathrm{O}_{5} /$ ha significantly enhanced the plant height, number of branches per plant, dry weight per plant, number and dry weight of nodules per plant, number of pods per plant, seeds per pod, seed yield (11.07 q/ha), stover yield (18.21 q/ha), crude protein content in seed and protein yield over control. Varieties showed significant influence in all characters except number and dry weight of nodules per plant and protein content. The highest seed yield was recorded in HUL 57(10.45 q/ha) which remained at par to DPL 62 (10.11 q/ha) and the lowest was observed in PL 4 (9.42 q/ha). Among the varieties, HUL 57 and DPL 62 were superior to PL 4 in respect of growth, yield and quality. HUL 57 fertilized with $40 \mathrm{~kg} \mathrm{P}_{2} \mathrm{O}_{5} /$ ha produced the highest seed yield.

\section{Introduction}

Pulses are an important group of crops which provide high quality protein for the predominantly vegetarian population of India. Pulses are the integral component of a cropping system in India as these crops fit well in crop rotation and mixed or inter cropping system followed under different agro-ecological regions.

Though India is the largest producer and consumer of pulses in the world, the average productivity is very low. The area, production and productivity under pulse crops accounts for 252.59 lakh ha, 16.47 million tonnes and
$652 \mathrm{~kg} / \mathrm{ha}$ respectively (Anon., 2016). Therefore, there is need to increase the pulse production in our country.

Lentil is one of the important pulse crops of India which can adapt well to a wide range of climate and soil condition. India occupies second position in lentil production in the world after Canada and is the fifth most important pulse crop in India in terms of production after chickpea, pigeon pea, mungbean and urdbean (Singh et al., 2015). In the country, lentil is cultivated in an area of about 1.27 million hectares with production of 0.97 million tonnes and average productivity of $765 \mathrm{~kg} / \mathrm{ha}$. (Anon., 2015-16). Lentil, being a 
leguminous pulse crop, fixes atmospheric nitrogen through root nodules by Rhizobium bacteria in which atmospheric nitrogen is converted into a plant usable form in the presence of nitrogenase enzyme. Thus, lentil restores the soil fertility and improves the soil health keeping the soil alive and productive.

Phosphorus is the key element for successful pulse production. Phosphorus enhances the root proliferation and nodulation in legume crops, increases dry matter production and seed yield (Sharma and Sharma, 2004; Balyan and Singh, 2005). Phosphorus is involved in several plant functions, including energy storage and transfer, photosynthesis, transformation of sugars and starches, nutrient movement within the plant and transfer of genetic characteristics from one generation to the next. Phosphorus is a constituent of ATP, nucleic acid, phospholipid, ADP, sugar phosphate, phytin, protein and several coenzyme. However, phosphorus is one of the major limiting nutrients for leguminous crops in acidic soil condition

Lentil yields at the farm level are far below the genetic potential of its cultivars. Growing of lentil in marginal and sub-marginal land, inadequate and imbalanced use of fertilizers as well as unavailability of site tested specific lentil varieties could be the contributing factors towards these lower production of yields. Most of the soils under lentil cultivation are low to medium in available phosphorus (P), therefore they respond positively to P-fertilizer application (Singh et al., 2005). The productivity of lentil can be improved by adopting suitable agrotechniques. Among the agro-techniques, growing of suitable variety well adapted to the climatic condition of the area and adequate application of phosphorus will result in better crop performance, seed yield and quality of lentil. However, the information on these aspects are lacking in the state. Keeping this in view, a field experiment was carried out during rabi season of 2016-17 to evaluate the most suitable variety of lentil and to identify the suitable dose of phosphorus.

\section{Materials and Methods}

The field experiment was carried out at the Research Farm of Agronomy, College of Agriculture, Central Agricultural University, Imphal, Manipur during the rabi season of 2016-17. The experimental site is located at $24^{\circ}$ $45^{\prime} \mathrm{N}$ latitude and $93^{\circ} 56^{\prime} \mathrm{E}$ longitude at an altitude of $790 \mathrm{~m}$ above the mean sea level. The soil of the experimental field was clay in texture with $\mathrm{pH} 5.57$ and having organic carbon $1.2 \%$, available nitrogen $288.51 \mathrm{~kg} / \mathrm{ha}$, available phosphorus $17.20 \mathrm{~kg} / \mathrm{ha}$ and available potassium $242.02 \mathrm{~kg} / \mathrm{ha}$. The mean minimum and maximum temperature recorded during the cropping season was 10.41 and $24.30^{\circ} \mathrm{C}$, respectively. During the experiment, the total rainfall recorded was $552.8 \mathrm{~mm}$. The average relative humidity in the morning hours was $87.39 \%$ and in the evening was $51.14 \%$. The average bright sunshine hour was 6.3 .

The treatment consisted of four levels of phosphorus $\left(\mathrm{P}_{0}\right.$-control, $\mathrm{P}_{1}-20 \mathrm{~kg} \mathrm{P}_{2} \mathrm{O}_{5} / \mathrm{ha}, \mathrm{P}_{2-}$ $\left.40 \mathrm{~kg} \mathrm{P}_{2} \mathrm{O}_{5} / \mathrm{ha}, \mathrm{P}_{3}-60 \mathrm{~kg} \mathrm{P}_{2} \mathrm{O}_{5} / \mathrm{ha}\right)$ and three varieties $\left(\mathrm{V}_{1}-\mathrm{PL} 4, \mathrm{~V}_{2}\right.$ - HUL 57 and $\mathrm{V}_{3^{-}}$DPL $62)$. The experiment was laid out in factorial randomized block design with three replications. Phosphorus as per treatment was applied through single superphosphate (SSP). A uniform dose of $20 \mathrm{~kg}$ N/ha and $20 \mathrm{~kg}$ $\mathrm{K}_{2} \mathrm{O} /$ ha were applied through urea and muriate of potash to all the plots along an open furrow at a distance $20 \mathrm{~cm}$ apart one day before sowing. The crop was sown by line sowing method at the rate of $50 \mathrm{~kg} / \mathrm{ha}$ on $10^{\text {th }}$ December, 2016. Thinning was done to maintain plant to plant distance of $5 \mathrm{~cm}$. Five representative plant samples were randomly selected from each plot and tagged. Height of 
the tagged plants was measured from ground level to the top of the shoot at harvest. The mean height was calculated and expressed in $\mathrm{cm}$. Five plants were collected from the destructive sampling rows at harvest . These fresh samples were air dried and then dried in an oven at $60 \pm 5^{\circ} \mathrm{C}$ till a constant weight was obtained and then weighed to record the average dry weight of plant $(\mathrm{g})$.

From the sampling rows of each plot, five plants were uprooted carefully and the soil adhering to the roots were washed out in clean water. The nodules from the roots were detached and counted to record the average number of nodules per plant at 60 and 90 DAS. After recording the number of nodules per plant, these nodules were dried in an oven to a constant weight to record the dry weight of nodules per plant (mg).

The number of primary branches per plant, pods per plant and seeds per pod were counted from the randomly selected plants of each plot and average was calculated. After complete sun drying, the weight of thoroughly sun dried plants of net plot were recorded and expressed as biological yield. After threshing and winnowing, grain and straw yield per plot were weighed and expressed as quintal per hectare. The sun dried 1000 seeds were randomly drawn from each plot for recording test weight $(\mathrm{g})$. The nitrogen percentage in lentil seeds was estimated in grounded seeds by using modified Kjeldahl's method (Jackson, 1967) and crude protein content was calculated by using the formula

\section{Crude protein content $(\%)=\% \mathrm{~N} \times 6.25$}

Protein yield (kg/ha) was calculated by multiplying protein content $(\%)$ and seed yield (q/ha). The data obtained was subjected to statistical analysis using the F-test (Gomez and Gomez, 1984).

\section{Results and Discussion}

The results obtained from the present investigation as well as relevant discussion have been summarized under the following heads:

\section{Effect of phosphorus}

Growth parameters like plant height, number of branches per plant, dry weight (g/plant), number of nodules per plant and dry weight of nodules per plant were significantly influenced by different phosphorus levels. A perusal of Table 1 revealed that plant height, number of branches per plant and dry weight of plant at harvest increased significantly with increasing phosphorus levels up to $40 \mathrm{~kg}$ $\mathrm{P}_{2} \mathrm{O}_{5} /$ ha over $20 \mathrm{~kg} \mathrm{P}_{2} \mathrm{O}_{5} / \mathrm{ha}$ and control. However, it remained statistically at par to 60 $\mathrm{kg} \mathrm{P}_{2} \mathrm{O}_{5} /$ ha. The maximum plant height (35.13 $\mathrm{cm})$, branches per plant (5.8) and dry weight (4.31g/plant) were recorded at $60 \mathrm{~kg} \mathrm{P}_{2} \mathrm{O}_{5} /$ ha. The highest number of nodules per plant was recorded at $60 \mathrm{~kg} \mathrm{P}_{2} \mathrm{O}_{5} / \mathrm{ha} \mathrm{(26.91)} \mathrm{where} \mathrm{it}$ remained at par to $40 \mathrm{~kg} \mathrm{P}_{2} \mathrm{O}_{5} / \mathrm{ha}$ (26.62) at 60 and 90 DAS. Again, in both the growth stages, the number of nodules per plant did not differ significantly between 40 and $20 \mathrm{~kg} \mathrm{P}_{2} \mathrm{O}_{5} / \mathrm{ha}$ but significantly higher than the control. Application of phosphorus showed marked improvement in dry weight of nodules per plant over control. The dry weight of nodules per plant increased significantly with every increase in the level of phosphorus up to $60 \mathrm{~kg}$ $\mathrm{P}_{2} \mathrm{O}_{5} /$ ha at 60 and 90 DAS except that application of $40 \mathrm{~kg} \mathrm{P}_{2} \mathrm{O}_{5} / \mathrm{ha}$ remained at par to $20 \mathrm{~kg} \mathrm{P}_{2} \mathrm{O}_{5} / \mathrm{ha}$ at $60 \mathrm{DAS}$. Phosphorus is essential for cell division, root development and proliferation, nodulation and nitrogen fixation. It is the main constituent of coenzymes, ATP, ADP and nucleic acid which acts as "energy currency" within plants. Almost every metabolic activity is regulated by phosphate derivatives. Thus, phosphorus is involved in energy transfer, photosynthesis, 
nucleic acid synthesis, membrane transport and cytoplasmic streaming. Increase in growth parameters owing to phosphorus application in the soil might be due to increase availability and uptake of soil nutrients by the crop contributed by phosphorus fertilization. The greater uptake of nutrients might have increased the photosynthetic ability and translocation of the metabolites to different parts which ultimately increased the root and shoot development of the crop. These findings corroborate the results of Zafar et al., (2003), Pandey et al., (2016) and Singh et al., (2016) in lentil and Kumawat et al., (2014) in green gram.

Application of phosphorus significantly increased the yield attributes like number of pods per plant and seeds per pod (Table 2). Though an increasing trend in test weight was observed with increasing application of phosphorus, phosphorus could not bring significant influence to test weight. Number of pods per plant increased significantly with increasing levels of phosphorus up to $40 \mathrm{~kg}$ $\mathrm{P}_{2} \mathrm{O}_{5} /$ ha (77.71) and further increase in the level of phosphorus up to $60 \mathrm{~kg} \mathrm{P}_{2} \mathrm{O}_{5} / \mathrm{ha}$ (79.79) did not bring significant difference in the number of pods per plant. The maximum number of seeds per pod (1.74) was recorded with the application of $60 \mathrm{~kg} \mathrm{P}_{2} \mathrm{O}_{5} / \mathrm{ha}$ and it remained at par to $40 \mathrm{~kg} \mathrm{P}_{2} \mathrm{O}_{5} / \mathrm{ha}$ (1.68). Again, application of $40 \mathrm{~kg} \mathrm{P}_{2} \mathrm{O}_{5} / \mathrm{ha}$ did not differ significantly with $20 \mathrm{~kg} \mathrm{P}_{2} \mathrm{O}_{5} / \mathrm{ha}$ (1.64). The lowest number of pods per plant (61.49) and seeds per pod (1.54) were recorded in control. The probable reason might be attributed to phosphorus fertilization in ensuring availability of other plant nutrients which increased carbohydrate accumulation and their remobilisation to reproductive parts of the plant, being the closest sink. Phosphorus is known to encourage flowering and fruiting which might have stimulated the plants to produce more pods per plant and also enables development of more number of seeds per pod. Similar findings were reported by Maqsood et al., (2000), Shah et al., (2000), Togay et al., (2008), Fatima et al., (2013) and Ali et al., (2017) in lentil.

Significant increase in the seed yield was recorded with the application of phosphorus up to $40 \mathrm{~kg} \mathrm{P}_{2} \mathrm{O}_{5} /$ ha over $20 \mathrm{~kg} \mathrm{P}_{2} \mathrm{O}_{5} /$ ha and control but remained statistically at par to 60 $\mathrm{kg} \mathrm{P}_{2} \mathrm{O}_{5} /$ ha (Table 2). Such a positive yield response of phosphorus application is obvious when it is limiting in acid soil. The soil samples $=$ analysed before starting the experiment indicated that the available phosphorus status of the soil in the experimental site was in medium range and thus responded well to the applied phosphatic fertilizer. Application of phosphatic fertilizer, therefore provided balance nutrition to the crop which resulted in higher seed yield of lentil. Phosphorus also increased the photosynthesis and translocation of assimilates to different plant parts for enhanced growth and yield attributing characters of the crop as observed in number of pods per plant and number of seeds per pod. In the later stage, the excess assimilates stored in the leaves was translocated towards sink development which ultimately contributed to higher seed yield. Significant increase in stover yield with the application of phosphorus up to $40 \mathrm{~kg} \mathrm{P}_{2} \mathrm{O}_{5} / \mathrm{ha}$ was also observed where it remained at par to $60 \mathrm{~kg} \mathrm{P}_{2} \mathrm{O}_{5} /$ ha (Table 2). The higher stover yield with suitable dose of phosphorus might be contributed by better growth of the plant as expressed in terms of plant height, number of branches per plant, fresh and dry weight of the plant as a result of improved nutrient uptake. These findings were supported by Choubey et al., (2013), Zeidan (2007) and Rasool and Singh (2016) in lentil.

Application of phosphorus significantly increased the crude protein content in seed and crude protein yield (Table 2). The maximum crude protein content in seed was recorded in 
$60 \mathrm{~kg} \mathrm{P}_{2} \mathrm{O}_{5} / \mathrm{ha}$ (24.19\%) which remained at par to $40 \mathrm{~kg} \mathrm{P}_{2} \mathrm{O}_{5} /$ ha but significantly superior to other levels of phosphorus. Again, $40 \mathrm{~kg}$ $\mathrm{P}_{2} \mathrm{O}_{5} /$ ha did not differ significantly in protein content as compared to $20 \mathrm{~kg} \mathrm{P}_{2} \mathrm{O}_{5} /$ ha. Crude protein yield increased significantly and consistently with every increase in the level of phosphorus up to $40 \mathrm{~kg} \mathrm{P}_{2} \mathrm{O}_{5} / \mathrm{ha}$ (264.81 $\mathrm{kg} / \mathrm{ha}$ ) and remained at par to $60 \mathrm{~kg} \mathrm{P}_{2} \mathrm{O}_{5} / \mathrm{ha}$. Phosphorus is an essential component of DNA and various forms of RNA which are needed for protein synthesis. As such application of phosphorus in adequate quantity enhanced the protein synthesis which resulted in higher protein content. Also, protein content is affected by nodulation which improved $\mathrm{N}$ concentration in seed. Increased $\mathrm{N}$ concentration might have increased the protein content which might be influenced indirectly by phosphorus application in improving the uptake of nutrients by the crop. The increase in crude protein yield may be attributed to increase in crude protein content in seed and seed yield with increasing phosphorus application. These results are in conformity with Niri et al., (2010), Pandey et al., (2016) and Sahu et al., (2017) in lentil.

\section{Effect of varieties}

Different varieties significantly influenced the growth parameters like plant height, number of branches per plant and dry weight of plant. Among the varieties, HUL 57 recorded the highest plant height at harvest and remained statistically at par to DPL 62. Again, DPL 62 remained at par to PL 4. The maximum number of primary branches was observed in HUL 57 and it showed significant superiority over DPL 62 and PL 4. The minimum number of branches was recorded in PL 4 which remained at par to DPL 62. The variety HUL 57 recorded the maximum dry weight per plant which remained at par to DPL 62 but significantly higher than PL 4. The minimum dry weight of plant was observed in PL 4 and it was at par to DPL 62. Varieties could not significantly influence the number of nodules per plant and dry weight of nodules per plant. However, the maximum number and dry weight of nodules per plant was recorded in DPL 64 and the lowest in PL 4. The difference in growth parameters among the varieties might be due variation in genetic make-up and cell division rate. These results are in agreement with those of Sen et al., (2016) and Singh et al., (2016).

Yield attributes like number of pods per plant, seeds per pod and test weight differed significantly with increasing application of phosphorus (Table 2). Among the varieties the number of pods per plant differed significantly. HUL 57 (76.7) recorded significantly higher number of pods per plant as compared to DPL 62 (72.18) and PL 4 (70.65).

However, DPL 62 and PL 4 remained statistically at par. The highest number of seeds per pod was recorded in the variety HUL 57 (1.71) and it remained at par to variety PL 4 (1.68). The lowest number of seeds per pod was recorded in DPL 62 (1.55) and was significantly inferior to HUL 57 variety and PL 4 variety. DPL 62 (29.2 g) gave significantly higher test weight compared to HUL 57 (19.5 g) and PL 4 (18.01 g). Again, HUL 57 recorded significantly higher test weight than variety PL 4 . The difference in yield attributes among the varieties might be due to the variation in genetic constitution. Similar findings were also reported by Datta et al., (2013), Yadav et al., (2016) and Zike et al., (2017) in lentil.

Seed yield and stover yield differed significantly among the different varieties (Table 2). The maximum seed yield was recorded in HUL 57 (10.45 q/ha) and it remained at par to DPL $62(10.11 \mathrm{q} / \mathrm{ha}$ and $)$ but significantly superior to PL 4 (9.84 q/ha). 
Table.1 Effect of phosphorus levels and varieties on growth characters of lentil

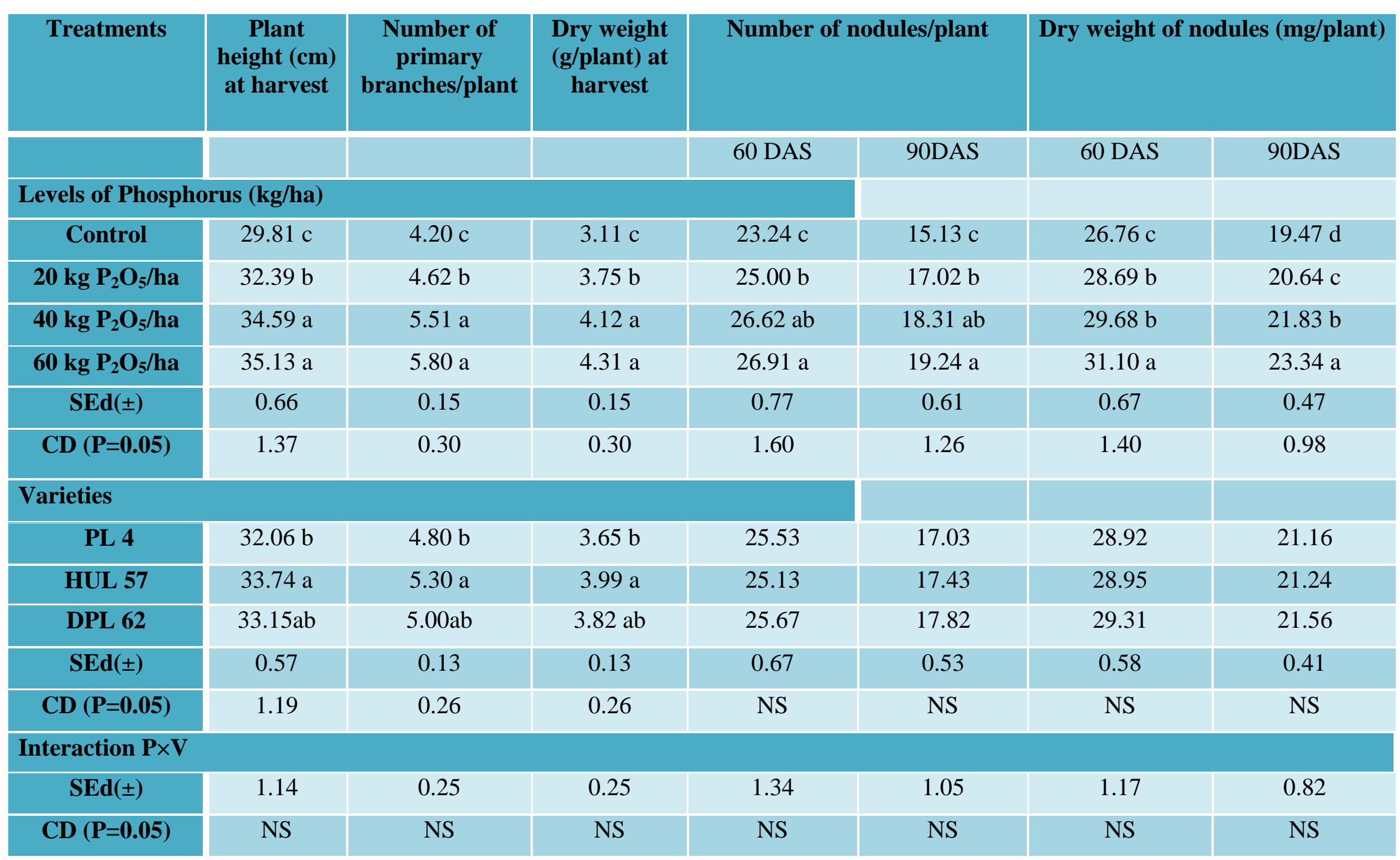

In a column figures having same letter(s) do not differ significantly whereas figures with dissimilar letter(s) differ significantly. 
Table.2 Effect of phosphorus and varieties on yield attributes, yield and quality of lentil

\begin{tabular}{|c|c|c|c|c|c|c|c|}
\hline Treatments & $\begin{array}{l}\text { Number of } \\
\text { pods/plant }\end{array}$ & $\begin{array}{l}\text { Number of } \\
\text { seeds/pod }\end{array}$ & $\begin{array}{l}\text { Test weight } \\
\text { (g) }\end{array}$ & $\begin{array}{l}\text { Seed yield } \\
\text { (q/ha) }\end{array}$ & $\begin{array}{c}\text { Stover yield } \\
\text { (q/ha) }\end{array}$ & $\begin{array}{c}\text { Protein } \\
\text { content }(\%)\end{array}$ & $\begin{array}{l}\text { Protein yield } \\
\text { (kg/ha) }\end{array}$ \\
\hline \multicolumn{8}{|c|}{ Levels of Phosphorus (kg/ha) } \\
\hline Control & $61.49 \mathrm{c}$ & $1.54 \mathrm{c}$ & 21.98 & $7.56 \mathrm{c}$ & $13.71 \mathrm{c}$ & $22.50 \mathrm{c}$ & $170.07 \mathrm{c}$ \\
\hline $20 \mathrm{~kg} \mathrm{P}_{2} \mathrm{O}_{5} / \mathrm{ha}$ & $73.71 \mathrm{~b}$ & $1.64 \mathrm{~b}$ & 22.25 & $9.84 \mathrm{~b}$ & $16.79 \mathrm{~b}$ & $23.25 \mathrm{~b}$ & $228.81 \mathrm{~b}$ \\
\hline $40 \mathrm{~kg} \mathrm{P}_{2} \mathrm{O}_{5} / \mathrm{ha}$ & $77.71 \mathrm{a}$ & $1.68 \mathrm{ab}$ & 22.33 & $11.07 \mathrm{a}$ & $18.21 \mathrm{a}$ & 23.91ab & $264.81 \mathrm{a}$ \\
\hline $60 \mathrm{~kg} \mathrm{P}_{2} \mathrm{O}_{5} / \mathrm{ha}$ & $79.79 \mathrm{a}$ & $1.74 \mathrm{a}$ & 22.39 & $11.51 \mathrm{a}$ & $18.36 \mathrm{a}$ & $24.19 \mathrm{a}$ & $278.51 \mathrm{a}$ \\
\hline $\operatorname{SEd}( \pm)$ & 1.26 & 0.04 & 0.63 & 0.22 & 0.53 & 0.36 & 7.15 \\
\hline $\mathrm{CD}(\mathrm{P}=0.05)$ & 2.62 & 0.09 & NS & 0.45 & 1.10 & 0.74 & 14.84 \\
\hline \multicolumn{8}{|l|}{ Varieties } \\
\hline PL 4 & $70.65 \mathrm{~b}$ & $1.68 \mathrm{a}$ & $18.01 \mathrm{c}$ & $9.42 \mathrm{~b}$ & $16.14 \mathrm{~b}$ & 23.42 & $221.45 b$ \\
\hline HUL 57 & $76.70 \mathrm{a}$ & $1.71 \mathrm{a}$ & $19.50 \mathrm{~b}$ & $10.45 \mathrm{a}$ & $17.35 \mathrm{a}$ & 23.44 & $246.22 \mathrm{a}$ \\
\hline DPL 62 & $72.18 b$ & $1.55 \mathrm{~b}$ & $29.20 \mathrm{a}$ & $10.11 \mathrm{a}$ & $16.81 b$ & 23.52 & $238.98 \mathrm{a}$ \\
\hline SE d ( $( \pm)$ & 1.09 & 0.04 & 0.55 & 0.19 & 0.46 & 0.31 & 6.20 \\
\hline $\mathrm{CD}(\mathrm{P}=0.05)$ & 2.27 & 0.08 & 1.13 & 0.39 & 0.96 & NS & 12.85 \\
\hline \multicolumn{8}{|l|}{ Interaction $\mathbf{P} \times \mathrm{V}$} \\
\hline SEd( $( \pm)$ & 2.18 & 0.07 & 1.09 & 0.37 & 0.92 & 0.62 & 12.39 \\
\hline $\mathrm{CD}(\mathrm{P}=0.05)$ & 4.53 & NS & NS & 0.77 & NS & NS & NS \\
\hline
\end{tabular}

In a column figures having same letter(s) do not differ significantly whereas figures with dissimilar letter(s) differ significantly. 
The maximum stover yield was recorded in HUL 57 (17.35 q/ha) and it remained significantly higher than PL 4 and DPL 62. However, PL 4 (16.14 q/ha) did not differ significantly with DPL 62 (16.81 q/ha).

The variation in seed and stover yield might be due to difference in growth characters like plant height, number of branches per plant and dry matter accumulation and also in yield attributing characters like number of pods per plant, seeds per pod and test weight among the varieties which is influenced by the geneticmake up. These results are in conformity with Sen et al., (2016), Yadav et al., (2016) and Iliger et al., (2017) in lentil.

Varieties could not bring significant influence in crude protein content in seed (Table 2). However, the highest crude protein content was recorded in DPL 62. Crude protein yield was significantly influenced by different varieties. The maximum crude protein yield was recorded in HUL $57(246.22 \mathrm{~kg} / \mathrm{ha})$ and it was at par with DPL $62(238.98 \mathrm{~kg} / \mathrm{ha})$ but significantly higher than PL $4(221.45 \mathrm{~kg} / \mathrm{ha})$. The differences in crude protein yield among the varieties might be contributed by seed yield and protein content. These findings were in agreement with Tomar et al., (2000) in lentil.

Based on the results of the present study, it can be concluded that application of phosphorus at $40 \mathrm{~kg} / \mathrm{ha}$ was found to be the optimum dose and HUL 57 and DPL 62 were found to be the best suited varieties for obtaining higher yield of lentil in Manipur.

\section{Acknowledgement}

The authors acknowledge the Head, Department for providing necessary facilities for conducting experiment, help and assistance in the preparation of manuscript of this article.

\section{References}

Ali, A., Ahmad, B., Hussain, I., Ali, A. and Shah, F.A. (2017). Effect of phosphorus and zinc on yield of lentil. Pure Appl. Biol., 6(4):1397-1402.

Anonymous (2015-16). Area, Production and Productivity of Masoor (Lentil) in India (1970-71 to 2015-16). Ministry of Agriculture and Farmers Welfare, Govt. of India.

Anonymous (2016). Fourth Advance Production Estimates of Major Crops During 2015-16. Department of Agriculture, Cooperation and Farmers Welfare, Govt. of India.

Balyan, J.K. and Singh, M. (2005). Effect of seed inoculation, different levels of irrigation and phosphorus on nodulation and root growth development of lentil.Res. Crops, 6(1): 32-34.

Choubey, S.K., Dwivedi, V.P. and Srivastava, N.K. (2013). Effect of different levels of phosphorus and sulphur on growth, yield and quality of lentil (Lens culinaris M). Indian J. Sci. Res., 4(2): 149-150.

Datta, S.K., Sarkar, M.A.R. and Uddin, F.M.J. (2013). Effect of variety and level of phosphorus on the yield and yield components of lentil. Int. J. Agril. Res. Innov. Tech., 3(1): 78-82.

Fatima, K., Hussian, N., Pir, F.A. and Mehdi, M. (2013). Effect of nitrogen and phosphorus on growth and yield of lentil (Lens culinaris).Elixir Appl. Bot., 57: 1432314325.

Gomez, K.A. and Gomez, A.A. (1984).Statistical procedures for Agricultural Research. John Wiley \&Sons, Singapore.

Iliger, M.D., Alagundagi, S.C., Patil, M.B. and Vijayakumar, A.G. (2017). Influence of seed rate and fertilizer levels on growth and yield of lentil (Lens culinaris Medik.) genotypes under dry land situation $J$. Pharmacogn. Phytochem., 6(6): 20192022.

Jackson, M.L. (1973). Soil Chemical Analysis. Prentice Hall of India Private Limited, New Delhi, pp. 498.

Kumawat, S.R., Khistriya, M.K., Yadav, S.L. and Kumar, M. (2014). Effect of sulphur and phosphorus on growth and yield attributes on summer green gram [Vigna 
radiata (L.) Wilczek].Int. J. Agric. Sci., 10(2): 770-773.

Maqsood, M., Zamir, M.S.I., Ali, R., Wajid, A. and Yousef, N. (2000). Effect of different phosphorus levels on growth and yield performance of lentil (Lens culinarisMedic).Pak. J. Biol. Sci., 3(3): 523-524.

Niri, H.H., Tobeh, A., Gholipouri, A., Zakaria, R.A., Mostafei, H. and Jamaati-e-Somarin, S. (2010). Effect of nitrogen and phosphorus on yield and protein content of lentil in dryland condition. Am-Euras. $J$. Agric. Environ. Sci., 8(2): 185-188.

Pandey, M.K., Verma, A. and Kumar, P. (2016). Effect of integrated phosphorus management on growth, yield and quality of lentil (Lens culinaris). Indian J. Agric. Res., 50(3): 238-243.

Rasool, S. and Singh, J. (2016). Effect of Biofertilizers and Phosphorus on Growth and Yield of Lentil (Lens culinaris L.).Int. J. Adv. Agril. Sci. Technol., 3(7): 35-42.

Sahu, G., Chatterjee, N. and Ghosh, G.K. (2017). Integrated nutrient management in lentil (Lens culinaris Medikus) in red and lateritic soils of West Bengal. Bull. Env. Pharmacol. Life Sci., 6(4): 55-62.

Sen, S., Ghosh, M., Mazumdar, D., Saha, B. and Dolui, S. (2016). Effect of sowing date and variety on phenology and yield of lentil during rabi season. J. Crop Weed, 12(1): 135-138.

Shah, S.H., Mahmood, M.Y. and Zamir, M.S.I. (2000). Qualitative and quantitative response of three cultivars of lentil (Lens culinaris Medic) to phosphorus application. Int. J. Agri. Biol., 2(3): 248250.

Sharma, B.C. and Sharma, S.C. (2004). Integrated nutrient management in lentil.Adv. Pl. Sci., 17(1): 195-197.

Singh, A.K., Singh, S.S., Prakash, V., Kumar, S. and Dwivedi, S.K. (2015). Pulses

\section{How to cite this article:}

Tophia Yumnam, Edwin Luikham and Herojit Singh A. 2018. Influence of Phosphorus on Growth and Yield of Promising Varieties of Lentil (Lens culinaris L. Medik). Int.J.Curr.Microbiol.App.Sci. 7(08): 162-170. doi: https://doi.org/10.20546/ijcmas.2018.708.021
Production in India: Present Status, Bottleneck and Way Forward. $J$. AgriSearch, 2(2): 75-83.

Singh, G., Singh, N. and Khanna, V. (2016). Growth of lentil (Lens culinaris Medikus) as influenced by phosphorus, rhizobium and plant growth promoting rhizobacteria. Indian J. Agric. Res., 50(6): 567-572.

Singh, K.K., Srinivasarao, C. and Ali, M. (2005). Root growth, nodulation, grain yield, and phosphorus use efficiency of lentil as influenced by phosphorus, irrigation, and inoculation. Commun. Soil Sci. Plant Anal., 36: 1919-1929.

Togay, Y., Togay, N. and Dogan, Y. (2008). Research on the effect of phosphorus and molybdenum applications on the yield and yield parameters in lentil (Lens culinaris Medic.) Afr. J. Biotechnol., 7(9): 12561260.

Tomar, S. K., Tripathi, P. and Rajput, A. L. (2000). Effect of genotype, seeding method and diammonium phosphate on yield and protein and nutrient uptake by lentil (Lens culinaris). Indian J.Agron., 45(1):148-152.

Yadav, A.C., Rai, O.P., Singh, S.P., Yadav, H.C., Yadav, R.K. and Kumar, N. (2016). To find out the suitable high yielding varieties of lentil for rainfed conditions of eastern Uttar Pradesh. Int. J. Agric. Sci., 12(2): 279-282.

Zafar, M., Maqsood, M., Anser, M.R. and Ali, Z. (2003). Growth and yield of lentil as affected by phosphorus. Int. J. Agri. Biol., 5(1): 98-100.

Zike, T., Abera, T. and Hamza, I. (2017). Response of improved lentil (Lens culinaris Medik) varieties to phosphorus nutrition on vertisols of West Showa, Central Highlands of Ethiopia. Adv. Crop Sci. Tech., 5(6): 315. 